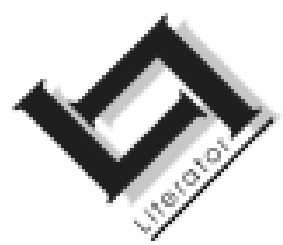

\title{
Towards accountability: A point of orientation for post-modern applied linguistics in the third millennium
}

\author{
Albert Weideman \\ Unit for Language Skills Development \\ University of Pretoria \\ PRETORIA \\ E-mail: ajweideman@postino.up.ac.za
}

\section{Abstract}

Towards accountability: A point of orientation for post-modern applied linguistics in the third millennium

In this article three difficulties in dealing with post-modern applied linguistics are identified, and three reasons are given for taking the trouble to define this emerging tradition of doing applied linguistics. In the context of earlier analyses of the history of applied linguistics, post-modernism is identified as a sixth generation of applied linguistic work. There are overlapping and unique features in each of these traditions. The discontinuity of a post-modern approach from first generation applied linguistics is noted, as are the numerous continuities with second, fourth, fifth and especially third generation work. These continuities go a long way towards characterising post-modern applied linguistics, yet are not sufficient to define it exhaustively. The biggest difficulty with such a characterisation appears to be a divergence within a post-modern approach. What holds this latest tradition together is the seriousness with which it deals with accountability, and in that lies, at present, its defining characteristic. Wherever one locates one's work, in earlier or in current traditions within applied linguistics, the premiss must always be to do these labours with integrity. Perhaps the latest trend towards an accountable applied linguistics has contributed more than any previous tradition to make us sensitive to this responsibility. 


\section{Opsomming}

Aanspreeklikheid as oriëntasiepunt vir postmoderne toegepaste taalkunde in die derde millennium

$A l$ is daar 'n drietal probleme met die hantering van 'n postmoderne toegepaste taalkunde, is daar net soveel goeie redes waarom 'n mens die moeite moet doen om hierdie ontluikende tradisie in die toegepaste taalkunde te definieer. Binne die konteks van vroeëre analises van die geskiedenis van die toegepaste taalkunde kan postmoderne toegepaste taalkunde ten beste beskryf word as 'n sesde tradisie. In elk van die ses tradisies wat ter sprake is, vind ons oorvleuelende en unieke kenmerke. Dié artikel identifiseer die diskontinuïteit tussen 'n postmoderne aanpak en die eerste tradisie van toegepaste taalkundige werk, asook die vele ooreenkomste met die tweede, vierde, vyfde en veral derde generasie van die toegepaste taalkunde. Met hierdie kontinuïteite kom 'n mens al 'n ver pad om postmoderne toegepaste taalkunde te karakteriseer, maar dit is tog nie voldoende nie. Die grootste enkele probleem vir die ondersoeker hier is 'n tweespalt wat binne die postmoderne toegepaste taalkunde bestaan. Dit blyk dat die erns waarmee die konsep "aanspreeklikheid" gehanteer word, inderdaad die uitstaande kenmerk van hierdie tradisie is. Ongeag binne watter van die ses generasies 'n mens ook al werk, dit wil sê in vroeëre of in latere tradisies, is die uitgangspunt immers altyd om hierdie werk met integriteit te verrig. Miskien is hierdie jongste tendens in die toegepaste taalkunde, naamlik om aanspreeklikheid hoog aan te slaan, meer as enige vorige tradisie daarvoor verantwoordelik dat ons sensitief geraak het vir die gevolge van ons werk.

\section{Characterisations of applied linguistics}

There are at least three paradoxes in doing applied linguistics in the emerging post-modern tradition. The first is that post-modernism as a trend now seems to define more and more scholarly work within the discipline, yet harbours within itself at least two identifiable strands. The second is that, what has at least in some quarters been understood as an alternative, critical movement, now has become the mainstream. The third is that post-modern applied linguistics is itself difficult to define: the variations in content within this developing tradition immediately make such an endeavour problematic. Perhaps, in the varied content of current work, we find a reflection of one of the common meanings of postmodernism, and one which serves as an illustration of the tradition better than anything else. In attempting to characterise this emerging approach, for example, Diane Larsen-Freeman's summary of her impressions of the 1996 AlLA conference captures the malaise well. She indicates that the post-modern tradition in applied linguistics is indeed still an emerging one. There are, she further contends, a number of tentative developments that have yet to come fully into their own. She concludes (Larsen- 
Freeman, 1997:90): "I take the observations that I have so far reported to be signs of a certain turmoil, a field in search of a new paradigm."

This sense of anticipation also emerges in Rampton's assessment made at roughly the same time, in the context of a review of applied linguistics, in which he remarks on the high level of enthusiasm for exploring uncharted territory among the authors of the papers he is introducing. He comments: "It is difficult to say whether this forward orientation reflects the end of a phase of fragmentation and the resurgence of a spirit of cross-disciplinary interchange that somehow got submerged after the early to mid '60s ..." (Rampton, 1997:16).

This article will explore not only the "forward orientation" that is mentioned here, but also some of the continuities among traditions of doing applied linguistics that Rampton's remark above refers to.

Of course, many who simply wish to get on with the work of doing applied linguistics would ask what the sense is of even attempting to characterise it. Yet there are at least three good reasons for attempting to characterise applied linguistics.

First, the notion of critical reflection is central in the post-modern tradition itself. It would be ironic, if not contradictory, if the current practitioners of such an approach were to deny themselves the opportunity to reflect upon their own enterprise, seeking to proceed with the business of coming forward with solutions to language problems in an unreflective manner, and in a way that remains deliberately ignorant of the history of the endeavour.

Second, consider the dilemma of someone entering the field. In the context in which I work, which is finding ways of making language instruction and language learning more effective, efficient and liberating, there is a considerable movement into the field of both mature academics who, for professional reasons, need to retrain themselves as language teaching specialists, and also of numbers of younger academics entering the profession. It would be irresponsible, in my view, to eliminate from their professional development and training a consideration of where they might locate themselves in the field that they have chosen to work. To leave historical trends unconsidered is to leave the initiates poorer.

It is true, certainly, that such reflection on one's place in the history of applied linguistics does not happen often. My argument is simply that it should happen much more frequently if we are to make sense of where the discipline comes from, and where it is at. 
Third, the context of my own work has no doubt also influenced the interest that I have, professionally, in characterising applied linguistics and locating my own work within a number of traditions and trends. In fact, as I have remarked above, the realisation that the post-modern trend now seems to define more and more scholarly work within the discipline, yet harbours within itself at least two identifiable strands, became more and more obvious to me as I was co-editing a recent tribute to the work of Keith Chick, a pioneer of applied linguistics in South Africa. In this tribute, Language and accountability: towards a socially sensitive applied linguistics (Adendorff, Kassanga \& Weideman, 2001), which was published as a special issue of the journal Southern African Linguistics and Applied Language Studies, there is just that mix and divergence that this article will seek to probe and discuss in some more detail below. Also, most of my own work has been in that part of applied linguistics that concerns itself with language teaching (cf. Weideman, 2002, and Weideman, 2003), and there is no doubt that an understanding of the history of applied linguistics in language teaching and learning is essential today, both if one wants to keep abreast of developments, and know what the pitfalls have been. Since South African applied linguistics has quite often been synonymous with designing language teaching, and even more often with English (second) language teaching, an historical understanding of the development of applied linguistics remains wholly relevant in the context in which I work. I believe that the same bias prevails in many other contexts worldwide, and, as a result, has the same relevance there.

How does one identify a particular trend in applied linguistics? How does one know how to define the tradition of applied linguistics within which one chooses to work? How do we relate, historically, the work that we do to different traditions of doing applied linguistics? Where do our current interests stand in relation to different orientations in applied linguistic work?

Elsewhere (Weideman, 1987; Weideman, 1999) I have dealt with the development of the various traditions within applied linguistics (see also Evensen, 1997:34 f.; McCarthy, 2001), and for the sake of brevity I shall not repeat here the detailed arguments for their identification as unique ways of doing applied linguistics. What is important, though, is that where earlier I believed that five broad development stages are discernible in the history of applied linguistics (for a detailed account, see Weideman, 1999), it is probably more accurate to distinguish at least six such models or traditions (or generations, for they follow one another) of doing applied linguistics: 


\begin{tabular}{|l|l|l|}
\cline { 2 - 3 } \multicolumn{1}{l|}{} & Model/Tradition & Characterised by \\
\hline 1 & Linguistic/behaviourist & "scientific" approach \\
\hline 3 & $\begin{array}{l}\text { Linguistic "extended paradigm } \\
\text { model" }\end{array}$ & language is a social phenomenon \\
\hline 3 & Multi-disciplinary model & $\begin{array}{l}\text { attention not only to language, but } \\
\text { also to learning theory and peda- } \\
\text { gogy }\end{array}$ \\
\hline 5 & $\begin{array}{l}\text { Coconstructivism } \\
\text { research }\end{array}$ & $\begin{array}{l}\text { experimental research into how } \\
\text { languages are learned }\end{array}$ \\
\hline 6 & Post-modernism & $\begin{array}{l}\text { knowledge of a new language is } \\
\text { interactively constructed }\end{array}$ \\
\hline
\end{tabular}

Each of these traditions has, to a greater or smaller extent, contributed to our academic knowledge of language education. However, not all of these traditions have had equally clear or thorough research agendas. Nor has each of the traditions been equally successful in generating such an agenda. In fact, the first generation of applied linguistics relied more heavily on theoretical assumptions than on subjecting them to critical analysis or empirical testing. Nonetheless, as the broad parameters within which applied linguistic work has been done, the six traditions mentioned above are also the contours within which, for the greater part, serious research has developed.

\section{Continuity and distinctiveness of traditions in applied linguistics}

How distinct are the above traditions as contexts in which applied linguistic work can be done? There is enough overlap and continuity between the successive traditions of language teaching and learning research for the user to be wary. In spite of the fact that they may be distinct, the research agenda initiated in one generation of applied linguistic work sometimes comes to fruition only in a subsequent tradition. In addition, in real time, a good number of the traditions discussed here have co-existed, and continue to do so. It is not as if the historical force of one tradition breaks down entirely, simply to be succeeded by another. I believe that these observations are crucial also 
for understanding the traditions that currently inform applied linguistic work.

If one wishes, therefore, to identify and characterise different traditions of doing applied linguistics, one would need to identify at least one thematic strand that makes each tradition unique, and then seek to discover how, at the same time, there is continuity, when a tradition either anticipates a subsequent one or expands it by taking further a concern of a former tradition.

The main contribution of the first tradition of doing applied linguistics is probably that the expectations that it set in motion, viz. that there are "scientific" solutions for language problems, continue to shape applied linguistic work.

Many of the "scientific" principles of this kind of applied linguistics have been shown to be wrong. Thus, for example, the notion that we should proceed in lockstep fashion, teaching bits of language from the grammatically simple to the grammatically more complex, finds no support in subject-related literature (Lightbown, 1985:181). Similarly, to accept that students must identify with the target culture (principle fifteen, mentioned in Lado, 1964:56) for the simple reason that many teachers believe this, though re-echoed subsequently in social acculturation explanations of second language acquisition and in the notion of integrative motivation, has been shown not to be valid for the Sesotho and Afrikaans learners of English that Coetzee-van Rooy (2000) surveyed: instead, their positive identification with their own identities correlated with good English proficiency.

The research agenda generated by first generation applied linguistics contributed to the development of contrastive analyses of the mother tongue and the target language (see below, the brief discussion of second language acquisition research). This agenda was itself contested, modified and superseded by others, but it provides a first illustration of the degree of overlap and continuity between the successive traditions of applied linguistics identified here.

The continuity that the second tradition in applied language studies has with the first is evident already in its intentions: it aimed to extend the linguistic basis of the work done by the founding fathers of the discipline. Regarding language as a social phenomenon, those working within this tradition posited that larger, socially relevant units of language were important for language teaching and learning. They found a new interest in distinguishing units like text, discourse, and register (see Widdowson, 1979). Their contribution was to broaden the idea of what it was that was 
being learned. One of the main interests of this tradition is how discourse coheres or hangs together (or fails to do so) in learners' use of the target language texts. Such studies (discussed by Connor, 1994:682-684; cf. too Halliday \& Hasan's 1976 work Cohesion in English, and, for South Africa, Hubbard's earliest work, e.g. Hubbard, 1993, on student writing) seek to describe the texts that learners produce, or the texts that need to be understood by learners. In the same broad tradition one finds Wilkins's (1976) work, which produced a taxonomy of language functions (instead of grammatical units) for a new, communicative kind of language teaching and learning.

Similarly, when this tradition gave way to a multi-disciplinary model of doing applied linguistics, it was an extension of the base of the discipline, but this time in an inter-disciplinary or multi-disciplinary direction. Now not only insights from linguistics were considered to be potentially beneficial to language teaching and learning, but it was acknowledged that pedagogy and that part of psychology that has to do with learning theory could also yield insights for the conduct of language teaching. Applied linguistics, as a discipline that had to do with the design of language teaching, was thus emancipated from relying solely on input from linguistic theory. Hence Johnson (1969:238), in an article significantly entitled "The failure of the discipline of linguistics in language teaching," noted that the lack of adequate criteria for the language content of courses can be blamed "on our willingness to simply accept linguistic data as the inviolate raw material" of these courses. So, instead of bringing linguistic procedures in unadulterated form into the design of second and foreign language courses, this tradition acknowledged that the pedagogical intervention of the teacher will always be crucial.

Today, the unmodified reflection of linguistic theory in language teaching is almost universally deplored. So, too, are the imperialistic designs of linguistic theorists that are implied by the name of the field - applied linguistics (for a review, cf. Van Els, Bongaerts, Extra, Van Os \& Janssenvan Dieten, 1984:128 ff.). The attention that Van Els et al. (1984) give to psychological and pedagogical considerations in language teaching design is an indication of how this imperialism has been contained.

One of the most important continuities of this tradition with current, postmodern orientations in applied linguistics lies not so much in the heritage of this trend in its broadening of the base of applied linguistics research, but in paving the way for the rise of a multi-disciplinary tradition in applied linguistics. Though it therefore did not so much generate a research agenda of its own, it consolidated and laid the foundation for technically more sophisticated investigations. The time was ripe for empirical studies of a number of aspects of language education. These 
empirical studies became the hallmark of the next tradition in applied linguistics, that of second language acquisition research, which took up especially the concern of how someone learns a new language.

The tradition of second language acquisition research signalled that investigation of language learning had reached a certain level of maturity. Initially, the interest of researchers was to determine the order of acquisition of certain morphemes and syntactic structures (cf. Truscott, 1996:337 for a discussion in the context of recent debate). Since an order of acquisition had been discovered in first language morphological development (for a summary, see Clark \& Clark, 1977:342 ff.), it was hypothesized that a similar order would be present in second language learning. Right up to the latest developments in linguistic theory, there have been hopes that one can synchronise language learning and instruction. The starting point for this kind of analysis is that there is an invariant order of acquisition that simply needs to be discovered. The further assumption is that the order is fixed because the genetically inbuilt, cognitive ability to learn a language is the same for all humans.

Of course, this is a starting point that is contested from a number of other positions, not the least from a social or interactionist perspective. The latter kind of interests soon developed into an investigation of how the structure not of the mind, but of discourse contributed to second language acquisition (cf. Cook, 1981; Hatch, 1978). In other words, these studies viewed the emergence of language as dependent on the structure of the interaction. Even at the so-called one-word stage, the studies demonstrated that the interaction or discourse structure provides slots for the words to fit into naturally. Hatch (1977:6), for example, provides some interesting social explanations for the discovery of a similar, invariant order of morphemes in both first and second language learners.

As we have noted before, one tradition within applied linguistics often takes up an issue raised first by an earlier tradition. Some of the earliest studies of second language acquisition were done within the framework of contrastive analysis, as envisaged by first generation studies in applied linguistics. Contrastive analysis, in its turn, was succeeded by error analysis, which attempted to describe learners' real errors, instead of predicting them. The problem, however, as Schachter (1974) points out, was that such an identification of errors could mask the fact that learners avoid certain structures because they have difficulty learning and mastering them. The example she gives is of Japanese and Chinese avoiding relative clauses in English because they have difficulty in producing them. Thus error analysis gave way to a number of other types of investigative frameworks, including interlanguage studies (which 
attempted to describe the way in which the language that adult second language learners used became "fossilized" at a certain stage, making it difficult for them, for example, to attain native-like pronunciation in it), performance analysis and sociolinguistic approaches (such as discourse analysis) (cf. Lightbown, 1985; Cook, 1978 for a survey of earlier work).

In the same way that this tradition of applied linguistics research takes up the research agenda of an earlier one, it also foreshadows, in the interactive explanations for the development of discourse competence, the fifth tradition, constructivism. Again, we should note that in our identification of distinct traditions within applied linguistics, we more often than not observe within them a continuity with the past and the future.

Second language acquisition research has today developed into a huge industry, and there have been many attempts to apply its findings. Since the inception of second language acquisition research, there have also been regular attempts, over a period of more than twenty years, to review the findings to see what implications there are for second language teaching (Tarone, Swain \& Fathman, 1976; Cook, 1978; Burt \& Dulay, 1981; Dulay, Burt \& Krashen, 1982; Lightbown, 1985; Lightbown \& Spada, 1993; Spada, 1997). The use of the term "implications"' instead of the stronger term "application" signals a much more sober expectation of the results of such research.

What do we learn then, from the increasingly sophisticated and sustained effort put into second language acquisition research? Apart from the implications mentioned in the literature referred to above, it is instructive to note that there are no clear indications from the research as to the order in which to teach language. As Nunan (2000:7) has recently remarked, with reference to a host of examples from his own experience and studies done on the actual learning process that students go through, "the relationship between teaching and learning is asymmetrical - in short ... learners do not learn what teachers teach in a linear, additive fashion". The most interesting point, therefore, is perhaps that the research has been able to tell us what does not work: "The method of proceeding step-by-step, from one grammatical building block to another - each block carefully and precisely placed, once and for all - simply finds no support in the research" (Lightbown, 1985:181).

Given the firmness of the tradition of conventional teaching, this finding is indeed a courageous one.

Constructivism, as a fifth historical way of doing applied linguistics, has indeed flourished over the last decade. In South Africa, the best examples of this tradition come from the work of the Threshold Project, 
which sought to inquire into the challenges for language teaching in black schools, and especially the problems associated with the previous policy of introducing English as medium of instruction from the fifth year of school onwards (for an accessible summary, cf. Macdonald \& Burroughs, 1991). The emphasis here is on revealing how learning is socially constructed through the medium of language, on the cognitive and reflexive strategies developed by learners, and on the role of teachers to facilitate such development. It goes without saying that this tradition is wholly opposed to transmission teaching, which views knowledge (of language, of science, of mathematics, and so on) as something that derives from that which an authority (for example the teacher, or the textbook) is able to pass on to learners (see Macdonald, 1988:120).

Also of importance to us in this tradition is that it gave some justification for the communicative approach to language teaching, where peer instruction (in the form of pair and group work) and a multitude of language communication tasks such as information gap exercises, role play tasks and group information gathering techniques, are regularly employed to allow the learner to build a language in interaction with others.

\section{Post-modern views within applied linguistics}

As we have seen in the preceding analysis, in some way every tradition of applied linguistics takes its cue from earlier traditions. There is, in each tradition, some new perspective, some novel angle on the way that we go about doing such work. But there is also continuity with what precedes a new tradition. Such continuity is signalled, usually, by a new tradition taking up a point first developed by an earlier tradition. As has been noted before, the notion of applied linguistics as a multi-disciplinary field did much to pave the way for a post-modern perspective. In this emerging tradition we rely not on a single view of academic endeavour and research - especially not on a positivist one - but acknowledge that there is a multiplicity of possible perspectives in the investigation of language teaching problems. The challenge, in the post-modern perspective, is to identify the conflicting and consensual aspects of such investigations.

The further challenge lies in identifying the political dimensions of, for example, language education. What effect do rigorously prescribed syllabuses have on teachers and learners who have had no say in their formulation? Whose authority can be invoked to legitimate the introduction of new language teaching methods on a national scale? How beneficial can language teaching to adults be if they are unable to set 
their own objectives and specify their own learning goals? What does the predominance of English as an international language do to the teaching of other languages, especially the languages of the politically powerless? How do existing language teaching elites justify their position and their domination of the field, and how can this be challenged?

All of these concerns, and a good number of others that also relate to language and the exercise of power, have in South Africa figured largely in the work of Keith Chick and his associates (cf. Chick, 1985; 1990). In South Africa, as elsewhere, the post-modern applied linguistics perspective on language education research would ask: what right does the academic researcher have to intervene in the sphere of competence of the teacher? Again, we can note that this question goes back to much earlier concerns; Chomsky (1966:263) had summarized the doubts of an earlier generation on this point as follows:

In general, the willingness to rely on 'experts' is a frightening aspect of contemporary political and social life. Teachers, in particular, have a responsibility to make sure that ideas and proposals are evaluated on their merits, and not passively accepted on grounds of authority, real or presumed.

Such concerns have led to the devising of research where the practitioner (e.g. the teacher) retains control, and influences the direction of the investigation.

The motivation for the post-modernist tendency within applied linguistics derives from an opposition to the goal of scientific endeavour since the Enlightenment, driven as that conception of science is by an idea of progressive improvement (cf. Brumfit, 1997:23, 24) that is achieved as a result of its analytical project. It is this very ideal, of course, that in the first instance led to the founding of applied linguistics. Brumfit (1997) also links post-modernism in our field to feminism, subjectivity, and relativity, but concludes that the extreme (relativist) positions that are possible as a result of these could make any theoretical work impossible; what we should rather learn from post-modern critiques of science is the valid criticism that is made of (potentially and actually) abusive, exploitative relations within the wider field of language teaching. Finally, Brumfit (1997:27) argues that this newest style of doing applied linguistics can contribute substantially to that entire tradition because "applied linguistics needs ... a plurality of approaches ... a recognition ... of alternative views ..."

It is this emphasis on more than one point of view that has made ethnographic description of language events such an important instrument in a 
post-modern approach. A cursory examination of ethnographic analytical techniques would also reveal the importance that such analysis attaches to context. Context is particularly important in ethnographic descriptions (Nunan, 1992:53) because it has a powerful influence on behaviour. By way of contrast, a language learning experiment may generate a context that is removed and distant from the classroom context in which the language must eventually be learned, and its results therefore may be quite irrelevant for classroom instruction. Instead, an ethnographic approach proposes that investigations are in the first instance conducted as field research, in situ, without seeking to manipulate the event and control all variables. These investigations often entail taking detailed field notes, and co-ordinating that information with other records, such as audio-recorded versions of lessons and transcripts of pivotal moments in the classroom interaction. Furthermore, the research is conducted not by the individual expert researcher alone, but is done in concert with other participants, like the language learners and teachers, whose views are taken into account through interviews, and the keeping of diaries and learning logs. Through such "thick" description - and by identifying the congruent moments from a diversity of perspectives - the ethnographic investigation attempts to build as rich a picture as possible of the context in which language learning takes place, so that generalisations that are helpful in interpreting the learning can be allowed to emerge.

This interpretive dimension is perhaps the defining characteristic of ethnographic research (see Nunan, 1992:57 f.). The interpretation that is the goal of the research can be checked not only by the participant researchers (researcher, teacher, students) among themselves, but could also be subjected to peer reviews, and the comparison of the findings to those reached in similar contexts. Thus "thick" descriptions are complemented by rich, multi-faceted explanations.

Applied linguistic researchers find ethnographic research alluring because it provides an antidote to the isolating, abstract character of experimental research. It can yield a depth of understanding that other approaches cannot match (Nunan, 1992:69). As Nunan (2000:6; cf. too Gebhard, 1999:547) would have it, "... at this stage in our work we are not looking for averages, norms, or generalizability, and we are not interested in populations and sample. In fact, we are happy to celebrate through our work the particular, the atypical, the unique".

The drawbacks, however, are that such investigation often requires longterm involvement, that one has to take all manner of precaution to ensure that the results are valid and reliable, and that it takes equally long to become a proficient and competent ethnographic researcher. But it can provide an alternative approach for those who are morally or 
politically uncomfortable with positivist research methodologies, and, though some purists would frown upon this, it can also usefully be combined with quantitative methods to give a multi-faceted perspective on language teaching and learning.

However, the interpretive strand within current work embodies only one theme of post-modern applied linguistics, which brings us to the first paradox identified at the beginning of this discussion. For many current researchers, the interpretive agenda of ethnographic description simply does not go far enough. Indeed, a solid component of post-modern applied linguistics would claim to have an unashamedly critical, and by that definition, political agenda. To an even greater extent than the investigative methodology of ethnographic description, critical and participatory approaches are designed to highlight the political dimensions of language relationships, such as in language teaching. These approaches are concerned, for example, with the uneven distribution of power among participants (learners and teachers) in the language classroom. Or they might seek to expose unequal relations among those who prescribe how language teaching must be done (i.e. curriculum designers and planners) and those who have to carry it out. Critical and participatory approaches present an alternative to dominant, mainstream approaches in "bringing into being new schemas of politicisation" (Pennycook, 1999:335). Essentially, their underlying philosophy is critical of positivist research strategies and pursuits, and in their work applied linguistics has made a $180^{\circ}$ turn from its beginnings in the linguistic/ behaviourist tradition. This constitutes a definite discontinuity with the founding tradition of applied linguistics.

A critical approach to language research not only investigates issues of inequality in learning situations, but seeks to change and transform such situations (Pennycook, 1994:691; 1999:335). The dominance of English as an international language, for example, deserves the attention of researchers. How does the teaching or learning of English affect the use of other (and especially indigenous) languages? How can resistance to the acceptance of dialects, as well as of regional varieties of English in the Caribbean and in Africa, be overcome? How does gender impede literacy, and what can be done to change the situation? What respect is there for minorities and their languages, and how can a lack of respect for these be eliminated? How is class privilege or racial difference reified by language teaching, and how can such a situation be transformed?

Critical approaches employ a range of research formats to answer these questions. In short, this direction "does not imply a particular approach to or method of research but rather is concerned with the extent to which research is answerable to larger moral and political questions" (Penny- 
cook, 1994:692). Nonetheless, it would avoid a positivist orientation, which constitutes a belief "in the efficacy of investigative procedures that emphasize quantification and prediction" (Pennycook, 1989:594). It is in this regard that Rampton (1995:233) refers to "a new set of social and political possibilities ... emerging for applied linguistics research". Critical pedagogy rejects the notion of disinterested knowledge or the assertion that science is neutral, and devoid of political interest. The procedures of science are, rather, the result of (mostly unequal) power relations, which it sets out to reveal and transform (cf. Pennycook, 1999:335).

Critical pedagogy is especially wary of progressivist notions inherent in much applied linguistic concept formation. Generally, it is inclined to deny that progress is inevitable when one subjects a problem to "scientific" analysis in the conventional Western understanding of the term. Pennycook (1989:601), for example, is sharply critical of the notion that the application of "scientific" principles to language teaching has achieved progress. Rather, he maintains, than presenting us with the results of steady, linear progress, the current language teaching situation is merely a "different configuration of the same basic options" (Pennycook, 1989:608). The causes for change in language teaching lie, in this view, in the main with social, political or philosophical factors. The task of critical applied language work would then be, first, to expose the myth of progressivist notions of science, of how scientific analysis or research was supposed to improve language teaching, and, second, to present an analysis that reveals the real (socio-political) reasons for transformation and change in language teaching.

One of the surest signs of the coming of age of this approach can probably be found in the special issue of TESOL Quarterly (Pennycook, 1999) that was recently devoted to it. Indeed, this maturity is evident in the encouragement of an ongoing, critical and reflexive engagement with critical approaches themselves (Pennycook, 1999:345). So, for example, Johnston (1999), though he acknowledges being professionally and personally influenced by critical pedagogy in his teaching, takes issue with several fundamental stances of a critical approach. He is particularly critical of the centrality in these approaches of politics, instead of moral interaction (cf. too Rampton, 1997:12):

It is my belief that critical pedagogy, though it frequently acknowledges the moral and ethical dimension of teaching, fails to perceive its centrality in the educational enterprise ... Such a position, in my view, falsifies the essential nature of education (Johnston, 1999: 561). 
Another clear sign of the academic maturity of critical approaches (it is interesting how wary one is initially to use the term "mainstreaming"!) can be discerned in the way that they take further and broaden the theoretical scope of second language acquisition studies that were the primary focus of fourth generation applied linguistic work (see above). Thus, Gebhard (1999:545 f.) makes a case for not treating the settings in which second languages are taught in the classroom as isolated from institutional structures and, hence, as politically neutral contexts. Her argument is for a contextual theory of classroom second language acquisition (1999:551), and she points out, persuasively, that "... institutional structures play a role in the distribution of discourses associated with academic success and school failure ... Therefore, schools reflect and enact an understanding of ... the status of $L 2$ users in society as a whole" (Gebhard, 1999:552).

In the examples of studies she refers to in this regard, it is clear that the organisational structure of the school, which might divide learners into the categories of "limited English proficiency" and, even, "learning disabled" play a substantial role in reinforcing rather than eliminating what they have defined as a problem. The treatment of the perceived problem is made worse, for example, by organisational arrangements that have low expectations of learners, and low levels of support for them in the form of textbooks and materials (Gebhard, 1999:553). Street (2000) makes essentially the same point about academic literacy and student writing in higher education institutions: instead of explaining writing problems as skills deficits, he argues, we need to refocus the discussion on the institutional context rather than the individual.

A final example of the coming of age of critical approaches comes from a contribution to the discussion of "critical literacy". Hammond and Macken-Horarik (1999:531) find themselves in agreement with some who have had to defend themselves against criticism from the side of those who subscribe to critical approaches to literacy. They find that "ongoing development of critical writing in English is dependent on [the] ability first to control the mainstream literacy requirements of the discipline" (Hammond \& Macken-Horarik, 1999:539). In concluding so, they do not abandon their starting point, which is that teachers are bound to create in their learners an awareness of the ideologies and power relations that work to the disadvantage of certain people and to the advantage of others, but are making a case for laying a sound (if conventional) foundation in literacy from the realistic vantage point of their practical experience. For the purposes of this discussion, it is significant to note that the radicalism of an initial position in this field has been tempered in the position taken up by these two writers. 
The extent to which critical approaches are today indeed regarded as mainstream - the second paradox referred to at the start of this article is also the point that occupies Billig (2000), who speaks of how "the growth of respectability entails the loss of critique as an intellectual activity". Indeed, there is a point of crisis for critical approaches when they themselves begin to constitute the accepted norm, gaining the position of orthodoxy. My analysis here has indicated that critical approaches have reached this point. At such a juncture, a critical, in essence anti-progressivist, orthodoxy might even be tempted to think of its own achievements in terms of progress! As Billig (2000:292) in fact notes: "We might talk of progress: the establishment of a critical paradigm, even as an intellectual orthodoxy, represents an improvement of what came before and what goes on elsewhere."

From my own personal and professional point of view, the historical accomplishment of this newest tradition of doing applied linguistics is that, by encouraging an approach that is critical of the power relations within our field, it has alerted us to how easy it is to fall prey to any strong tradition. This is also the point succinctly made in a recent analysis by McCarthy (2001: especially the final number of sections, 130-143). Elsewhere (Weideman, 1999; 2002) I have commented on how the responsibility of any training in applied linguistics must be to avoid making those at the receiving end of our designs the victims of such design and tradition. Tradition is about history and historical power, also in applied linguistics.

\section{A new point of orientation for applied linguistics}

There is little doubt, in my view, that the analysis given here has identified, in this most recent tradition of doing applied language work, at least two trends: an interpretive, ethnographically inclined line of thinking, and a critical, politically sensitive direction. This discussion has also dealt with some of the possible historical explanations for the tradition "that somehow got submerged": several influential intervening traditions. In fact, in describing this "resurgence", Rampton (1997) affirms the continuity of what I have called sixth generation applied linguistics with what preceded it. Though he goes to some lengths to point out the differences between Widdowson's later views and critical approaches, his analysis (Rampton, 1997) in fact indicates that in a crucial respect the latter hark back also to second generation applied linguistics, in which Widdowson figured prominently. For example, the very notion that characterised second generation applied linguistics, the extension of the linguistic basis of applied linguistics, is embodied in Hymes's idea of communicative competence (vs. the narrowly conceived linguistic competence of 
Chomskyan theory). Rampton (1997:8) also demonstrates how Hymes conceived of not only a linguistics that extends existing theory, but also of a "socially constituted" linguistics that would assist in overcoming inequalities in language, as well as concern itself with social structure (Rampton, 1997:9). This clearly foreshadows the social and ethical objectives of the current tradition of doing applied linguistics.

The six successive traditions of doing applied linguistic research have been characterised as embodying a "progression [that] can be seen as a continuous dialectic between an autonomous and idealised vision of language and a socially accountable view" (Brumfit, 1997:22; for these terms, cf. also Rampton, 1995, and Street, 2000; Street had apparently used them as early as 1984). Certainly, the post-modern tradition that is emerging intends to take the issue of accountability seriously, and in that perhaps lies, at present, its defining orientation and characteristic.

The inability of applied linguistic work to fulfil the promise of its early scientifically inspired zeal should encourage humility, even today, where we design solutions inspired by different starting points and technologies than at the inception of the discipline. In fact, language problems crying out for solutions seem to increase all the time. Current practitioners would no doubt accuse first generation work in language education research (and perhaps fourth, or even fifth generation, such is the continuity) of a structural, in-built arrogance, viz. the attitude that one needs merely to subject the language problem to scientific analysis to arrive at a solution. But one would need to warn too, then, of a missionary hubris that sixth generation work could fall prey to. The history of our work, which we share even with those whose very starting points we today strongly contest, inspires humility. In my own field, that of language teaching, I can think of a handful of truly liberating methods. For every emancipatory practice and methodology, however, there are other practices and methodologies that have ensnared teachers and made them into victims of the designed solution (Weideman, 2002). The continuity of our work makes us responsible for both.

Wherever one locates one's work, in earlier or in current traditions within applied linguistics, the premiss must be to do these labours with integrity. Perhaps the newest trend, towards an accountable applied linguistics, has contributed more than any previous tradition to make us sensitive to this responsibility.

\section{Acknowledgements}

This paper both condenses and amplifies views that I have had the privilege of sharing and debating with others for some time. I am particularly grateful to 
those who have listened patiently (current colleague Christo van Rensburg and former colleague Dirk van den Berg), but I also wish to thank specifically a small number who have at various stages contributed to the debate and my own subsequent understanding: Ralph Adendorff, Gary Barkhuizen, Susan Coetzee-van Rooy and Doug Young. I am also grateful to three anonymous reviewers and the editor for identifying points that could be improved.

\section{Bibliography}

Adendorff, R., Kassanga, L. \& Weideman, A.J. (eds.) 2001. Language and accountability: towards a socially sensitive applied linguistics. Special issue of Southern African Linguistics and Applied Language Studies, 19.

Billig, M. 2000. Towards a critique of the critical. Discourse \& Society, 11(3):291-292.

Brumfit, C. 1997. Theoretical practice: applied linguistics as pure and practical science. In: Mauranen, A. \& Sajavaara, K. (eds.) Applied linguistics across disciplines. AlLA Review, 12 1995/6. Milton Keynes : AlLA. p. 18-30.

Burt, M. \& H. Dulay. 1981. Optimal language learning environments. In: Alatis, J.E., Altman, H.B. \& Alatis, P.M. (eds.) The Second Language Classroom: Directions for the 1980's. New York : Oxford University Press. p. 175-192.

Chick, K. 1985. The interactional accomplishment of discrimination in South Africa. Language in Society, 14(3):299-326.

Chick, K. 1990. Language acquisition or language socialization? The case for ethnographic input to an ESL course for undergraduates. In: Chick, K. (ed.) Searching for relevance: contextual issues in applied linguistics in Southern Africa. Durban : SAALA. p. 302-324.

Chomsky, N. 1966. Linguistic theory. Reprinted in: Smolinski, F. (ed.) 1985. Landmarks of American language \& linguistics. A resource collection for the overseas teacher of English as a foreign language. Washington, D.C. : United States Information Agency. p. 262-266.

Clark, H.H. \& Clark, E. 1977. Psychology and language. New York : Harcourt Brace Jovanovich.

Coetzee-van Rooy, S. 2000. Cultural identity profiles of Afrikaans and Southern Sotho speakers of English as a second language - resource or hazard? Paper presented at the CALSSA conference, University of Cape Town. 11 December.

Connor, U. 1994. Text analysis. In: Cumming A. (ed.) Alternatives in TESOL research: descriptive, interpretive, and ideological orientations. TESOL Quarterly, 28(4):682-684.

Cook, V.J. 1978. Second-language learning: a psycholinguistic perspective. Language Teaching and Linguistics: Abstracts, 11:73-89.

Cook, V.J. 1981. Second language acquisition from an interactionist viewpoint. Interlanguage Studies Bulletin, 6(1):93-111.

Cumming, A. (ed.). 1994. Alternatives in TESOL research: descriptive, interpretive, and ideological orientations. TESOL Quarterly, 28(4):673-703.

Dulay, H., Burt, M. \& Krashen, S. 1982. Language Two. New York : Oxford University Press.

Evensen, L.S. 1997. Applied linguistics within a principled framework for characterizing disciplines and transdisciplines. In: Mauranen, A. \& Sajavaara, K. (eds.) Applied linguistics across disciplines. AlLA Review, 12 1995/6. Milton Keynes : AlLA. p. 31-41.

Gebhard, M. 1999. Debates in SLA studies: redefining classroom SLA as an institutional phenomenon. TESOL Quarterly, 33(3):544-556. 
Halliday, M.A.K. \& Hasan, R. 1976. Cohesion in English. London : Longman.

Hammond, J. \& Macken-Horarik, M. 1999. Critical literacy: Challenges and questions for the ESL classroom. TESOL Quarterly, 33(3):528-544.

Hatch, E. 1977. An historical overview of second language acquisition research. In: Henning, C.A. (ed.) Proceedings of the Los Angeles Second Language Research Forum. Mimeo. p. 1-14.

Hatch, E. 1978. Discourse analysis, speech acts, and second language acquisition. In: Ritchie, W.C. (ed.) Second language acquisition research: issues and implications. New York : Academic Press. p. 137-155.

Hubbard, E.H. 1993. Some coherence correlates in expository writing. South African Journal of Linguistics Supplement, 15:55-74.

Johnson, F.C. 1969. The failure of the discipline of linguistics in language teaching. Language Learning, 19(3 \& 4):235-244.

Johnston, B. 1999. Putting critical pedagogy in its place: a critical account. TESOL Quarterly, 33(3):557-565.

Lado, R. 1964. Language teaching: a scientific approach. New York : McGraw-Hill.

Larsen-Freeman, D. 1997. Impressions of AILA 1996. In: Mauranen, A. \& Sajavaara, K. (eds.) Applied linguistics across disciplines. AILA Review, 12 1995/6. Milton Keynes : AILA. p. 87-92.

Lightbown, P.M. 1985. Great expectations: second language acquisition research and classroom teaching. Applied Linguistics, 6(2):173-189.

Lightbown, P.M. \& Spada, N. 1993. How languages are learned. Oxford : Oxford University Press.

Macdonald, C. 1988. Teaching primary science in a second language: two teaching styles and their cognitive concomitants. In: Weideman, A.J. (ed.) Styles of teaching and styles of learning. Proceedings of the 6th Southern African Applied Linguistics Association conference. Bloemfontein : University of the Orange Free State. p. 115-127.

Macdonald, C. \& Burroughs, E. 1991. Eager to talk and learn and think: bilingual primary education in South Africa. Cape Town : Maskew Miller Longman.

Mauranen, A, \& Sajavaara, K. (eds.). 1997. Applied linguistics across disciplines. AILA Review, 12 1995/6. Milton Keynes : AILA.

McCarthy, M. 2001. Issues in applied linguistics. Cambridge : Cambridge University Press.

Nunan, D. 1992. Research methods in language learning. Cambridge : Cambridge University Press.

Nunan, D. 2000. Seven hypotheses about language teaching and learning. TESOL Matters, 10(2):1-9.

Pennycook, A. 1989. The concept of method, interested knowledge, and the politics of language teaching. TESOL Quarterly, 23(4):589-618.

Pennycook, A. 1994. Critical pedagogical approaches to research. In: Cumming, A. (ed.) Alternatives in TESOL research: descriptive, interpretive, and ideological orientations. TESOL Quarterly, 28(4):690-693.

Pennycook, A. 1999. Introduction: Critical approaches to TESOL. TESOL Quarterly (Special topic issue: Critical approaches in TESOL), 33(3):329-348.

Rampton, B. 1995. Politics and change in research in applied linguistics. Applied Linguistics, 16(2):233-256.

Rampton, B. 1997. Retuning in applied linguistics. International Journal of Applied Linguistics, 7(1):3-25.

Schachter, J. 1974. An error in error analysis. Language Learning, 24(2):205-214. 
Spada, N. 1997. Form-focussed instruction and second language acquisition: a review of classroom and laboratory research. Language Teaching, 30:73-87.

Street, B.V. 2000. Academic literacies and the 'New communicative order': implications for research and practice in student writing in HE. Keynote address at the CALSSA conference, University of Cape Town. 11 December. MSS (several handouts and a summary).

Tarone, E., Swain, M. \& Fathman, A. 1976. Some limitations to the classroom applications of current second language acquisition research. TESOL Quarterly, 10(1):19-32.

Truscott, J. 1996. Review article: The case against grammar correction in L2 writing classes. Language Learning, 46(2):327-369.

Van Els, T, Bongaerts, T., Extra, G., Van Os, C. \& Janssen-van Dieten, A. 1984. Applied linguistics and the learning and teaching of foreign languages. London: Edward Arnold.

Weideman, A.J. 1987. Applied linguistics as a discipline of design: a foundational study. Bloemfontein : University of the Free State. (D. Litt. thesis).

Weideman, A.J. (ed.). 1988. Styles of teaching and styles of learning. Proceedings of the 6th Southern African Applied Linguistics Association conference. Bloemfontein : University of the Orange Free State.

Weideman, A.J. 1999. Five generations of applied linguistics: some framework issues. Acta Academica, 31(1):77-98.

Weideman, A.J. 2002. Designing language teaching: on becoming a reflective professional. Pretoria : BE at UP.

Weideman, A.J. 2003. Academic literacy: prepare to learn. Pretoria : Van Schaik.

Widdowson, H.G. 1979. Directions in the teaching of discourse. In: Brumfit, C.J. \& Johnson, K. (eds.) The communicative approach to language teaching. Oxford : Oxford University Press. p. 49-60.

Wilkins, D.A. 1976. Notional syllabuses: a taxonomy and its relevance to foreign language curriculum development. Oxford : Oxford University Press.

\section{Key concepts:}

accountability

applied linguistics

history

post-modern

\section{Kernbegrippe:}

geskiedenis

post-modern

toegepaste taalkunde

aanspreeklikheid 